\title{
THE IMPACT OF THE ADOPTION OF INTERNATIONAL FINANCIAL REPORTING STANDARDS ON THE FINANCIAL SITUATION AND PERFORMANCE OF THE COMPANY
}

\author{
Radoslav Tusan ${ }^{1}$ \\ DOI: https://doi.org/10.31410/LIMEN.S.P.2020.37
}

\begin{abstract}
This paper deals with the evaluation of the impact of the adoption of International Financial Reporting Standards (IFRS) on the financial situation and performance of the company. The Slovak Accounting Act allows accounting and reporting under IFRS for two types of entities - explicitly specified by law (e.g. banks, insurance companies, stock exchange); and those that meet specified size criteria. The analyzed company met the size criteria and IFRS has been applying since 2018. The transition from Slovak accounting procedures to IFRS has an impact on the classification of individual items of assets and liabilities, their structure, and the classification of related costs and revenues. The transition to IFRS thus has an impact on the company's financial position and performance. The paper set out two objectives of the research: 1) the transition to IFRS caused an insignificant change in the company's financial indicators; 2) the transition to IFRS caused a significant change in the company's financial indicators. The results of the analysis show changes in the structure of the company's assets and liabilities, the amount of income and expenses, and the less significant impact of the adoption of IFRS on financial indicators.
\end{abstract}

Keywords: Accounting, Reporting, Financial statements, Financial ratios.

\section{INTRODUCTION}

$\mathrm{T}$

The intention of adopting IFRS was to create a unified information base for entities that entered global capital markets. This intention is implemented by the IFRS Foundation and the International Accounting Standards Board (IASB) in a single set of globally accepted financial reporting standards. The European Union has adopted this reporting framework since 2005. Since this year, many countries in Asia, Africa, Europe, Latin America, Canada, and also in the US, have adopted IFRS for companies registered on the capital markets. Current International Financial Reporting Standards (IAS/IFRS) and their interpretations (SIC/IFRIC) are in force. Thus, the adoption of IFRS not only by the EU has become a link between accounting information providers and their users in the global market. The first adoption of IFRS is governed by a separate IFRS 1 First-time Adoption of International Financial Reporting Standards. When an entity is adopting IFRS for the first time, a lot of issues have to be resolved. These issues relate to recognition, classification, measurement, presentation and disclosure. In principle, IFRS 1 requires companies implementing international standards to apply retrospectively all IFRS effectively at the end of the company's first IFRS reporting period. 
However, the standard provides a number of mandatory exceptions and optional exemptions to the requirement for a full retrospective application of IFRS. Mandatory exceptions relate to estimates, de-recognition of non-derivative financial assets and non-derivative financial liabilities, hedge accounting and non-controlling interests. The exceptions are to prevent the situation that the cost of a full retrospective application of IFRS would exceed the potential benefit to users of the financial statements. According to Mackenzie et al., (2012): "Steps in transition to IFRS involves the following: selection of accounting policies that comply with IFRS; and preparation of opening IFRS balance sheet at the date of transition. It covers recognition of all accounting items whose recognition is required under IFRS, de-recognition of accounting items if IFRS does not permit such, reclassification and measuring of items according to principles outlined in IFRS" (p. 935).

Research on the adoption of IFRS can be oriented in two directions - on the economic context and the enterprise context. Fewer authors focus on the enterprise level, probably due to a smaller database and time base. This can be seen especially with entities in Central and Eastern European countries where capital companies and capital markets exist to a lesser extent. Although previous research has investigated the economic consequences of IFRS adoption, there is less evidence on the impact of IFRS adoption on key financial ratios. However, the Slovak Accounting Act defines the accounting units that are required to prepare financial statements following international standards. These are the following: banks, commercial insurance companies, pension companies, Railways of the Slovak Republic, Stock Exchange. Mandatory application is also if a business entity has met, in at least two successive accounting periods, no fewer than two of the following requirements: its total assets exceeded EUR 170 000 000; net turnover exceeded EUR 170000 000; and the average number of employees exceeded 2000. An accounting entity, which has issued securities in the accounting period and these have been admitted to trading on a regulated market (Stock Exchange), shall prepare the individual financial statements according to IAS/IFRS and its optional decision. In case when an entity prepares consolidated financial statements, then IFRS is applicable mandatory.

\section{LITERATURE REVIEW}

Bryce, et al. (2015) examined whether accounting quality has improved following the adoption of IFRS. They investigated if audit committees are more effective in promoting accounting quality under IFRS. They used the Jones (1991) and Dechow et al. (1995) models to verify the hypotheses. The authors concluded that accounting quality is not significantly enhanced after the adoption of IFRS in Australia, and the audit committees are generally more effective in promoting accounting quality under IFRS than previous Australian GAAP (p. 180). Chua et al. (2012) examined the mandatory implementation of IFRS and its impact on the quality of accounting from three perspectives: earnings management, timely loss recognition, and value relevance. They concluded, that "the pervasiveness of earnings management by way of smoothing has reduced, while the timeliness of loss recognition has improved post-adoption. Additionally, the value relevance of financial statement information has improved, especially for non-financial firms" (p. 119). The impact of IFRS adoption on the quality of consolidated financial reporting was an interesting subject of research (Müller, 2014). He observed book value of equity per share and earnings per share of the parent company and confirmed: "A higher level of quality surplus (increment) supplied by group statements (as opposed to parent company financial statements) in the context of applying IFRS as opposed to applying national regulations for consolidated reporting" (p. 981). This author was "ascertained (according to predictions) that an increase in the quality surplus (increment) supplied by group financial 
statements compared to parent company individual financial statements once the adoption of IFRS became mandatory for preparing consolidated financial statements" (p. 982).

The impact of IFRS adoption in Europe and Australia on the relevance of book value and earnings for equity valuation was examined by Clarkson et al. (2011). They considered an alternative non-linear "product model" which incorporates the cross-product of book value (book value per share) and earnings (earnings per share) into the model. According to Clarkson et al. (2011), "The use of Product model was justified and should be considered by future researchers when doing levels valuation research" (p. 16). Outa (2011) observed the impact of IFRS adopting with value relevance which "Tries to associate a firm's value as expressed in stock prices to the reported income statement and balance sheet" (p. 220). The arguments used were around the fact that IFRS possibly improves the book values (valuation measurements) at the expense of net income (Outa, 2011). Blanchette, et al. (2013) made the comparison of accounting figures and financial ratios computed under IFRS and pre-changeover Canadian GAAP (CGAAP) for the same period using a sample of 150 companies listed on the Toronto Stock Exchange which mandatorily adopted IFRS. The research revealed, that "Central values of IFRS financial statement figures and ratios are not significantly different from those derived under CGAAP as the equality of means and the equality of medians are not statistically rejected for all figures and ratios, except one - net profit/loss" (p. 5).

Beneish, et al. (2015), stated, "IFRS adoption has a significantly greater effect on foreign debt than on foreign equity investment flows. This result is consistent with the notion that debt investors are greater consumers of financial statement information. We find that the increase in foreign equity investment around IFRS adoption is limited to countries that had higher governance quality, economic development, and creditor rights before IFRS adoption" (p. 24). DeFond et al. (2011) hypothesized, that the mandatory adoption of a uniform set of accounting standards, such as IFRS, attracts greater investment by foreign mutual funds if the standards increase financial reporting comparability. They found "that mandatory IFRS adoption results in a greater increase in foreign investment among companies in countries with strong implementation credibility that experience relatively large increases in uniformity" (p. 256). They also found "that these are the only firms with a significant increase in foreign mutual fund ownership" (p. 256). Similar research led Gordon et al. (2012). They examined the IFRS impact on the foreign direct investment (FDI) of developing and developed countries with a crosssectional, time-series, benchmark model. Gordon et al. concluded, that "The overall FDI inflows are positively associated with a country's decision to adopt IFRS" (p. 393). They found support for the stated argument that "this support is statistically significant for those countries classified as developing economies, but not for countries classified as developed economies" (p. 393). As stated Lungu, et al. (2017): "The countries adopting IFRS are more likely to benefit from a higher increase in FDI inflows than the non-adopters" (p. 331).

Renders and Gaeremynck (2007) observed the impact of legal and voluntary investor protection in relation to IFRS adoption. They found that "IFRS adoption depends on the level of investor protection. Companies refrain from adopting IFRS before it becomes mandatory in 2005 because of opportunistic behavior by management in countries with weak investor protection". Furthermore, they found "that corporate governance recommendations have the same impact on IFRS adoption as hard laws and can compensate for the negative impact of weak laws" (p. 64). Similarly, Verriest et al. (2013) stated: "Results show that stronger governance firms disclose more information, comply more fully and use IAS 39's carve-out provision less opportunistically“ (p. 39). Jiao et al. (2011) compared analyst data before and after the mandatory adoption of IFRS in nineteen European countries. They found, that "analyst 
forecasts have become more accurate and less dispersed after the adoption of IFRS" (p. 62). Kim et al. (2012) researched the relationship between audit fees and mandatory adoption of the IFRS. They found, that "the IFRS-related audit fee premium increases with the increase in audit complexity brought about by IFRS adoption, and decreases with the improvement in financial reporting quality arising from IFRS adoption" (p. 2061).

Goodwill, research and development expenses, asset revaluation, the book value of equity, and earnings were observed by Aharony et al. (2010). They confirmed their hypothesis, that: "In the year before the mandatory adoption of the IFRS, the incremental value relevance to investors of the three domestic GAAP-based accounting items was greater in countries where the respective domestic standards were more compatible with the IFRS" (p. 535). Lantto and Sahlström, (2009) pointed out the significant impact of the adoption of IFRS on the key financial indicators of Finnish entities (p. 341). Similarly, Aubert and Grudnitski explored significant differences in return on assets (ROA) for firms computed under IFRS and local, generally accepted accounting principles. They concluded, that "Specifically, there was no statistical support for any of the samples that accounting information produced under IFRS was any more value relevant than the accounting information derived using local generally accepted accounting principles" (p. 1). Italian companies that have adopted IFRS have been reviewed by Cameran et al. (2014) to determine the impact on earnings quality. Their results pointed that: "IFRS adoption did not improve reporting quality among private companies but, on the contrary, decreased it" (p. 278). Research on the impact of mandatory IFRS adoption on initial public offer (IPO) underpricing led Hong et al. (2014). They found "a decrease in IPO underpricing and an increase in the relative proceeds from foreign markets following mandatory IFRS adoption" (p. 1365). Hakalová et al. (2017) analyzed globalization trends in financial accounting, especially IFRS. According to them, "Using IFRS as a basis for determining income tax base could bring a number of benefits, but of course, it is also associated with disadvantages" (617), also, Hakalová et al., (2014), (p. 193).

A review of the literature on the impact of IFRS adoption has made Zaidi and Paz, (2015). The authors conducted literary research on the adoption of IFRS for economic growth, and the harmonization of accounting information. Further, they reviewed literature sources on the relationship between IFRS and earnings, the cost of capital, and the qualitative aspect of accounting information. They commented on the benefits and drawbacks of the above findings.

\section{METHODOLOGY}

The subject of the analysis is a company that has adopted IFRS for size reasons. The date of the company's transition to IFRS was September 30, 2019. As of this date, the company has prepared financial statements following IFRS and national accounting legislation (NAL) as well. Differences between a reported asset and liability items were assessed for materiality. Materiality is defined in IAS 1 as: "Item presented in the financial statements if its omission or misstatement would influence or change the economic decisions of users made based on the financial statements" (Mackenzie, 2012, p. 42). Significance was set at 3\% of the volume of assets (Arens et al., 2003, p. $210 €$ ). That is, 3\% of the sum of assets 146577 thousand $€$, is 4,397 thousand $€$. The impact of the items was then reflected in the financial indicators. Changes in financial indicators were assessed in terms of their impact on user decision-making.

This paper set out two objectives of the research:

1) transition to IFRS caused an insignificant change on the company's financial indicators;

2) transition to IFRS caused a significant change on the company's financial indicators. 


\section{RESULTS}

The analyzed company manufactures components for cars with a wide range of customers. It met the size criteria for the transition to IFRS as of September 30, 2018. Non-current assets under IFRS are higher by $€ 5610$ thousand $€$. It is a deferred tax asset and national legislation recognizes it in current assets. Accrual items (6 757 thousand $€$ ) were reported separately according to national legislation, under IFRS they belong to current assets. National legislation reports long-term provisions separately (257 thousand $€$ ), while IFRS includes them in noncurrent liabilities. Short term credits ( 2570 thousand $€$ ) and short term provisions (17 462 thousand $€$ ), short term provisions and accruals (736 thousand $€$ ) were reported separately according to national legislation, under IFRS they belong to current liabilities. Changes in the classification of asset and liability items after the transition to IFRS did not affect the balance sheet total. Also, changes in the values of expenses and revenue did not affect the profit after tax.

Table 1. Impact of the transfer on the company's assets and liabilities

\begin{tabular}{|c|c|c|c|c|c|}
\hline \multicolumn{2}{|c|}{$\begin{array}{c}\text { Statement of Financial } \\
\text { Position as of 30.9.2019 } \\
\text { (IFRS) }\end{array}$} & \multirow[t]{2}{*}{ Change } & \multicolumn{2}{|c|}{$\begin{array}{c}\text { Balance Sheet as of } 30.9 .2019 \\
\text { under national legislation }\end{array}$} & \multirow[t]{2}{*}{$\begin{array}{l}\text { Material } \\
\text { change }\end{array}$} \\
\hline Assets & thousands $€$ & & Assets & thousands $€$ & \\
\hline $\begin{array}{l}\text { Noncurrent } \\
\text { assets }\end{array}$ & 44932 & 5610 & $\begin{array}{l}\text { Noncurrent } \\
\text { assets }\end{array}$ & 39322 & yes \\
\hline \multirow[t]{2}{*}{$\begin{array}{c}\text { Current } \\
\text { assets }\end{array}$} & 101645 & 1147 & $\begin{array}{c}\text { Current } \\
\text { assets }\end{array}$ & 100498 & no \\
\hline & & & Accruals & 6757 & yes \\
\hline Total assets & 146577 & 0 & Total assets & 146577 & none \\
\hline $\begin{array}{c}\text { Equity and } \\
\text { liabilities }\end{array}$ & thousands $€$ & & $\begin{array}{c}\text { Equity and } \\
\text { liabilities }\end{array}$ & thousands $€$ & \\
\hline Equity & 2083 & 0 & Equity & 2083 & \\
\hline \multirow[t]{2}{*}{$\begin{array}{c}\text { Noncurrent } \\
\text { liabilities }\end{array}$} & 50422 & 167 & $\begin{array}{l}\text { Noncurrent } \\
\text { liabilities }\end{array}$ & 50255 & no \\
\hline & & & $\begin{array}{l}\text { Long term } \\
\text { provisions }\end{array}$ & 257 & \\
\hline \multirow[t]{3}{*}{$\begin{array}{c}\text { Current } \\
\text { liabilities }\end{array}$} & 94072 & 20885 & $\begin{array}{l}\text { Current } \\
\text { liabilities }\end{array}$ & 73187 & yes \\
\hline & & & $\begin{array}{c}\text { Short term } \\
\text { credits }\end{array}$ & 2597 & \\
\hline & & & $\begin{array}{l}\text { Short term } \\
\text { provisions }\end{array}$ & 17462 & \\
\hline \multirow[t]{2}{*}{$\begin{array}{c}\text { Total } \\
\text { liabilities }\end{array}$} & 144494 & 736 & $\begin{array}{c}\text { Total } \\
\text { liabilities }\end{array}$ & 143758 & no \\
\hline & & & Accruals & 736 & no \\
\hline $\begin{array}{l}\text { Total equity } \\
\text { and liabilities }\end{array}$ & 146577 & 0 & $\begin{array}{c}\text { Total equity } \\
\text { and liabilities }\end{array}$ & 146577 & none \\
\hline
\end{tabular}

Source: Own computation based on financial statements 
Following the transition to IFRS, the company reported revenues from continuing operations in the amount of 345656 thousand $€$. According to NAL, the value of these revenues was 347 709 thousand $€$. The decrease of 2053 thousand $€$ is due to the fact that IFRS in the income from continuing operations include only revenue from the main activity, while revenue according to NAL also includes revenue from the sale of assets. Reduction of production expenses is related to other divisions according to IFRS - for selling and administrative expenses. Under IFRS, financial revenue does not include foreign exchange gains and financial expenses do not include foreign exchange losses. Foreign exchange gains and losses are included in other revenue and other expenses (IFRS).

Table 2. Impact of the transfer on the company's revenues and expenses, in thousand EUR

\begin{tabular}{|c|c|c|c|c|c|}
\hline \multicolumn{2}{|c|}{$\begin{array}{l}\text { Statement of Comprehensive } \\
\text { Income for year ended } \\
\text { September 30, 2019 (IFRS) }\end{array}$} & \multirow[t]{2}{*}{ Change } & \multicolumn{2}{|c|}{$\begin{array}{l}\text { Income Statement for } \\
\text { year ended September } 30 \text {, } \\
2019 \text { under national } \\
\text { accounting legislation }\end{array}$} & \multirow[t]{2}{*}{$\begin{array}{c}\text { Material } \\
\text { change }\end{array}$} \\
\hline \multicolumn{2}{|c|}{ Continuing operations } & & & & \\
\hline Revenue & 345656 & 2053 & $\begin{array}{c}\text { Operating } \\
\text { revenues }\end{array}$ & 347709 & no \\
\hline $\begin{array}{c}\text { Operating } \\
\text { expenses }\end{array}$ & -285690 & 59892 & $\begin{array}{c}\text { Operating } \\
\text { expenses }\end{array}$ & -344972 & yes \\
\hline $\begin{array}{c}\text { Selling and } \\
\text { administrative } \\
\text { expenses }\end{array}$ & -57905 & & & & \\
\hline Other income & 2061 & & & & \\
\hline Other expenses & -1543 & & & & \\
\hline $\begin{array}{l}\text { Profit/loss from } \\
\text { operating } \\
\text { activities }\end{array}$ & 2579 & 158 & $\begin{array}{l}\text { Profit/loss } \\
\text { from } \\
\text { operating } \\
\text { activities }\end{array}$ & 2737 & no \\
\hline Finance revenue & 28 & 156 & $\begin{array}{l}\text { Finance } \\
\text { revenue }\end{array}$ & 184 & no \\
\hline Finance costs & -3386 & 313 & $\begin{array}{c}\text { Finance } \\
\text { costs }\end{array}$ & -3699 & no \\
\hline $\begin{array}{l}\text { Profit/loss before } \\
\text { tax }\end{array}$ & -779 & 0 & $\begin{array}{l}\text { Profit/loss } \\
\text { before tax }\end{array}$ & -779 & \\
\hline Tax expense & 2740 & 0 & Tax expense & 2740 & \\
\hline $\begin{array}{l}\text { Profit after tax } \\
\text { from continuing } \\
\text { operations }\end{array}$ & 1961 & 0 & $\begin{array}{c}\text { Profit after } \\
\text { tax }\end{array}$ & 1961 & none \\
\hline
\end{tabular}

Source: Own computation based on financial statements

Liquidity, indebtedness, activity and profitability ratios did not change significantly after the adoption of IFRS. Liquidity ratios are below the recommended values due to low cash. The company is too indebted $(98,58 \%)$. Activity indicators are at an average level. Earnings before interest, taxes, depreciation and amortization (EBITDA) are presented favorably. 
Table 3. Impact of the transfer on the company's indicators

\begin{tabular}{|c|c|c|}
\hline & IFRS 2019 & $\begin{array}{c}\text { National accounting } \\
\text { legislation 2019 }\end{array}$ \\
\hline Cash ratio & 0,08 & 0,08 \\
\hline Quick ratio & 0,90 & 0,85 \\
\hline Current ratio & 1,08 & 1,08 \\
\hline Debt ratio & $98,58 \%$ & $98,08 \%$ \\
\hline Receivables collection period & 43,8 days & 40,1 days \\
\hline Payables outstanding period & 65,5 days & 65,5 days \\
\hline Inventories turnover period & 24,8 days & 24,8 days \\
\hline EAT & 1961 thousand $€$ & 1961 thousand $€$ \\
\hline EBITDA & 8738 thousand $€$ & 8738 thousand $€$ \\
\hline
\end{tabular}

Source: Own computation based on financial statements

\section{CONCLUSION}

Research on the adoption of IFRS can be oriented in two directions - on the economic context and the enterprise context. Many authors have examined the impact of the adoption of IFRS on value relevance and earning management. Fewer authors focused on the enterprise level, probably due to a smaller database and time base. This can be seen especially with entities in Central and Eastern European countries where capital companies and capital markets exist to a lesser extent. Although previous research has investigated the economic consequences of IFRS adoption, there is less evidence on the impact of IFRS adoption on key financial ratios. It was an interesting finding that almost all cited authors (except Hakalová) dealt with entities in Western Europe, Canada, respectively in Australia. This indicates an insufficiently researched issue in the case of Central and Eastern European entities.

The paper aimed to observe if the transition to IFRS caused an insignificant or significant change on the company's financial indicators. The transition to IFRS reporting did not result in significant changes in the financial situation or performance of the company. Slight changes in ratios were due to the reclassification of certain types of assets and liabilities to IFRS requirements. Significant changes were only partial, in the reporting of individual items, where IFRS differs from the national accounting legislation. The focus of future research may be to examine the impact of the adoption of IFRS on the corporate level of new members of the European Union.

\section{ACKNOWLEDGMENT}

This research was supported by the project VEGA no. 1/0866/21: The use of analytical tools to detect manipulation in the financial statements of state and local government entities in the context of a true and fair view of accounting.

\section{REFERENCES}

Aharony, J., Barniv, R., Falk, H. (2010). The Impact of Mandatory IFRS Adoption on Equity Valuation of Accounting Numbers for Security Investors in the EU. European Accounting Review, 19(3), 535-578. https://doi.org/10.1080/09638180.2010.506285

Arens, A. A., Elder, R. J., \& Beasley, M. S. (2003). Essentials of Auditing and Assurance Services. New Jersey: Prentice Hall. 
Aubert, F., Grudnitski, G. (2010). The Impact and Importance of Mandatory Adoption of International Financial Reporting Standards in Europe. Journal of International Financial Management \& Accounting, 22(1), 1-26. https://doi.org/10.1111/j.1467646X.2010.01043.X

Beneish, M. D., Miller, B. P., Yohn, T. L. (2015). Macroeconomic evidence on the impact of mandatory IFRS adoption on equity and debt markets. Journal of Accounting and Public Policy, 34(1), 1-27. https://doi.org/10.1016/j.jaccpubpol.2014.10.002

Bryce, M., Ali, M. J., Mather, P., R. (2015). Accounting quality in the pre-/post-IFRS adoption periods and the impact on audit committee effectiveness - Evidence from Australia. Pacific-Basin Finance Journal, 35(Part A 2015), 163-181. http://dx.doi.org/10.1016/j.pacfin.2014.12.002

Blanchette, M., Racicot, F., \& Sedzro, K. (2013). IFRS Adoption in Canada: An Empirical Analysis of the Impact on Financial Statements. Toronto, Canada: Certified General Accountants Association of Canada.

Cameran, M., Campa, D., Pettinicchio, A. (2014). IFRS Adoption Among Private Companies: Impact on Earnings Quality. Journal of Accounting, Auditing \& Finance, 29(3), 278-305. https://doi.org/10.1177/0148558X14534260

Chua, Y., L., Cheong C., S., Gould, G. (2012). The Impact of Mandatory IFRS Adoption on Accounting Quality: Evidence from Australia. Journal of International Accounting Research, 11(1), 119-146 https://doi.org/10.2308/jiar-10212

Clarkson, P., Hanna, J., D., Richardson, G., D., Thompson, R. (2011). The impact of IFRS adoption on the value relevance of book value and earnings. Journal of Contemporary Accounting \& Economics, 7(1), 1-17. http://doi:10.1016/j.jcae.2011.03.001

DeFond, M., Hu, X., Hung, M., Li, S. (2011). The impact of mandatory IFRS adoption on foreign mutual fund ownership: The role of comparability. Journal of Accounting and Economics, 51(3), 240-258. https://doi:10.1016/j.jacceco.2011.02.001

Gordon, L., A., Loeb, M., P., Wenjie, Z. (2012). The impact of IFRS adoption on foreign direct investment. Journal of Accounting and Public Policy, 31(4), 374-398. http://dx.doi.org/10.1016/j.jaccpubpol.2012.06.001

Hakalová, J., Palochová, M., \& Pšenková, Y. (2017). Globalization Trends in Financial Accounting and Taxation of Business Entities in Compliance with the Implementation of EU Directives and Upcoming Recodification of Tax Legislation in the Czech Republic. In: $17^{\text {th }}$ International Scientific Conference Globalization and Its SocioEconomic Consequences. October $4^{\text {th }}-5^{\text {th }}, 2017$ (pp. 613-620). University of Zilina, The Faculty of Operation and Economics of Transport and Communications, Department of Economics.

Hakalová, J., Pšenková, Z., \& Losová, M. (2014). First-time Adoption of International Financial Reporting Standards for Business Corporations Based in EU Member State that are Issuers of Securities Admitted to Trading on Regulated Market. In I. Honová, et al. (Ed.), Proceedings of the $2^{\text {nd }}$ International Conference on European Integration. May $15^{\text {th }}-16^{\text {th }}, 2014$, (pp. 192-201). Ostrava: VŠB-Technical University of Ostrava.

Hong, H., A., Hung, M., Lobo, G., J. (2014). The Impact of Mandatory IFRS Adoption on IPOs in Global Capital Markets. The Accounting Review, 89(4), 13651397.https://doi.org/10.2308/accr-50720

Jiao, T., Koning, M., Mertens, G., Roosenboom, P. (2011). Mandatory IFRS adoption and its impact on analysts' forecasts. International Review on Financial Analysis, 21, 56-63. https://doi:10.1016/j.irfa.2011.05.006

Kim, J., B., Liu, X., Zheng, L. (2012). The Impact of Mandatory IFRS Adoption on Audit Fees: Theory and Evidence. The Accounting Review, 87(6), 2061-2094 https://doi.org/10.2308/accr-50223 
Lantto, A., M., Sahlström,P., (2009). Impact of International Financial Reporting Standard adoption on key financial ratios. Accounting \& Finance, 49(2), 341-361. https://doi.org/10.1111/j.1467-629X.2008.00283.x

Lungu, C., I., Caraiani, Ch., Dascălu, C. (2017) The Impact of IFRS Adoption on Foreign Direct Investments: Insights for Emerging Countries, Accounting in Europe, 14(3), 331357 https://doi.org/10.1080/17449480.2017.1374546

Mackenzie, B., Coetsee, D., Njikizana, T., Chamboko, R., Colyvas, B., \& Hanekom, B. (2012). Interpretation and Application of International Financial Reporting Standards. New Jersey: Wiley and Sons Inc.

Müller, V., O. (2014). The impact of IFRS adoption on the quality of consolidated financial reporting. Procedia - Social and Behavioural Sciences, 109, 976-982. https://doi:10.1016/j.sbspro.2013.12.574

Outa, E. R. (2011). The Impact of International Financial Reporting Standards (IFRS) Adoption on The Accounting Quality of Listed Companies In Kenya. International Journal of Accounting and Financial Reporting, 1(1), 212-241.

Renders, A., Gaeremenyck, A. (2007). The Impact of Legal and Voluntary Investor Protection on the Early Adoption of International Financial Reporting Standards (IFRS). De Economist, 155, 49-72. https://doi.org/10.1007/s10645-006-9041-y

Verriest, A., Gaeremynck, A., Thornton, D., B. (2013) The Impact of Corporate Governance on IFRS Adoption Choices. European Accounting Review, 22(1), 3977.https://doi.org/10.1080/09638180.2011.644699

Zaidi, S., Paz, V. (2015). The impact of IFRS adoption: a literature review. Journal of

Theoretical Accounting Research, 10(2), 116-141. 